\title{
Diving into Tripadvisor.com: Analysing tourists' perspectives towards Layang-Layang Island, Sabah, Malaysia
}

\author{
Andi Tamsang Andi Kele \\ Faculty of Business, Economics and Accountancy, Universiti \\ Malaysia Sabah, Malaysia \\ andi@ums.edu.my
}

\section{Yuzainy Janin}

Faculty of Business, Economics and Accountancy, Universiti Malaysia Sabah, Malaysia

zayy@ums.edu.my

\author{
Arif Kamisan Pusiran (corresponding author) \\ Faculty of Business, Economics and Accountancy, Universiti \\ Malaysia Sabah, Malaysia \\ arif@ums.edu.my
}

\section{Rafiq Idris}

Faculty of Business, Economics and Accountancy, Universiti Malaysia Sabah, Malaysia

rafiq.idris@ums.edu.my

\section{Publication Information:}

Received 3 February 2021, Accepted 19 May 2021, Available online 29 June 2021

DOI: $10.21463 /$ jmic.2021.10.1.12

\section{Abstract}

For countries that are geographically blessed with islands, island tourism is a potential segment that can be exploited, especially in view of the intense competition in attracting tourists to the Southeast Asian region. Layang-Layang Island, Malaysia, which is located in the middle of the South China Sea is a renowned diving destination known for its hammerhead sharks and other pelagic marine life. Despite having hosted tourists (particularly divers) for nearly two decades, Layang-Layang Island is much under-researched. Therefore, this study aims to investigate the tourist experience in Layang-Layang Island by utilising online reviews extracted from the TripAdvisor website. Leximancer software was utilised to analyse the data and generate concepts out of words. Five themes were derived from the data analysis which flight, resort, diving, day and reef. The findings provide insights into the positioning of Layang-Layang Island from the tourists' perspectives and maybe a useful reference for its future development.

\section{Keywords}

Tourist experience, Layang-Layang Island, online reviews, TripAdvisor 


\section{Introduction}

Island tourism has been increasingly important due to the intense competition to attract tourists, particularly in the Southeast Asian region (Sangpikul, 2017). Tourism is a vital attribute for economic, environmental, social and cultural development, especially for small islands (Lee, Jan, Tseng and Lin, 2018). Island destinations are alternatives to the mainland for tourists to be exposed to various travel experiences such as spectacular landscape, abundant natural resources, land and water-based facilities, local history and culture, and a variety of accommodation options (Prayag and Ryan, 2012).

However, many of these attributes that contribute to islands' tourist attractiveness often pose obstacles to island tourism's long-term development (Conlin and Baum, 1995). Islands frequently face difficulties due to their remote and peripheral nature and population and land area size (Ismail, Alipiah, Mansor and Shukri, 2020). A few of the most serious issues that characterise each of these conditions are small domestic markets, limited resources, limited infrastructure and accessibility, diseconomies of scale, and a high degree of reliance on external influences (Stylidis, Terzidou and Terzidis, 2007). As a matter of fact, tourism is typically more essential for small islands than the mainland, as small islands depend on tourism to generate their economy. Thus, it is crucial to understand tourists' experience to design proper measures to attract tourists, directly affecting islands' economy and development.

Furthermore, tourism is an experience-driven industry; tourists place a high value on their overall experiences to meet their satisfaction. Tourist experiences are recognised as one way for tourism businesses to differentiate themselves and achieve a competitive advantage in the market. This is especially important for island tourism, which is heavily reliant on tourist experiences, influencing their satisfaction.

As tourists explore places, their sense of smell, taste, hearing, sight, and touch are with their reasoning ability and previous encounters; thus, the tourist experience is enhanced across different environments and contexts (Oliveira, Brochado, Moro and Rita., 2019). Experience is the core of tourism activity and comprises a cognitive, affective and behavioural nature (Souza, Kasternholz, Barbosa and Calvalho, 2020). Some researchers believe that the tourist experience should be assessed through a holistic perspective, while others state that the notion of the overall experience influences the experience directly (Hassenzahl and Tractinsky, 2006).

For the study method, the researchers utilised the Leximancer software to analyse the content of online reviews platform instead of the conventional research approach such as interviews, survey or questionnaires. Researchers such as Munar and Jacobsen (2013) and Oliveira et al. (2019) discussed the significance of online tourist review platforms like TripAdvisor in assessing tourist experience. Specifically, Munar and Jacobsen (2013) assessed tourists' views of online data sources and determined the relationship between online social media and information sharing by the tourists, whereas Oliveira et al. (2019) investigated tourist experience in the Islands of Cape Verde using online reviews and further stated that There was limited research examining the tourist experience using online reviews, especially in the small island context.

The researchers' site of the study was Layang-Layang Island, located in the heart of the South China Sea, approximately 300 kilometres northwest of Sabah, East Malaysia. This small island is well-known in the diving world as one of the best diving destinations due to its hammerhead sharks (Musa, Kadir and Lee, 2006). This study aims to identify the 
determinants underlying the tourist experience on Layang-Layang Island by utilising the online reviews extracted from the TripAdvisor website, with the support of the Leximancer software.

Tourist experience and destination attributes have been the subject of research worldwide. However, research on island destinations, especially in Malaysia, has been limited. Given the industry's relevance to the growth of small islands in Malaysia, it is critical to determine the factors that influence tourist experiences. Thus, the current study aims to make three contributions to the small island tourism literature. Firstly, this study contributes to further understanding the tourist experiences on small island destinations by utilising the tourists' online reviews, which has been relatively limited compared to conventional research approaches. The study also contributes to the literature related to tourism and consumer behaviour in a cross-cultural context of Layang-Layang Island, Malaysia. Additionally, the study contributes to the literature related to service quality and destination attributes.

In order to generate positive tourist experiences, researchers have attempted to explore the contributing factors that influence tourists' experiences. The purpose of tourist experience research is to maximise profits for the tourism-related business (Chen and Chen, 2010) and improve a development strategy to sustain the tourism product's competitiveness and long-term viability (Jennings, Stoker and Bowers, 2009). Understanding tourists' experiences on small islands are beneficial not only for the profit but also for guiding management initiatives to maintain its long-term viability (Kurniasari, 2019).

\section{Island Tourism}

Wilkinson (2010) estimates that there are over 87 microstates in the world, separated into islands and non-islands. Researchers have attempted to conceptualise the idea of smallness from an economic perspective. Small countries are referred to as price takers, whereas larger countries are referred to as price setters. On the other hand, the latest concepts include Gross Domestic Product (GDP), land area and population as criteria for defining small states. For instance, Bass and Dalal-Clayton (1995) described a small state as smaller than $1,000 \mathrm{~km}^{2}$ in size and has a population of fewer than one million people. According to Sheldon (2005), islands can be classified by climate (cold, temperate or tropical), single island or archipelago, the governance of the island (autonomous or part of mainland system), the homogeneity or heterogeneity of the population, and the proximity to its size (mainland or small island).

Islands have been used as places of rest and relaxation for thousands of years. For instance, during the Roman period, the Isle of Capri was a popular vacation destination. With the surge of mass tourism in the middle of the twentieth century, islands have become important tourist destinations (Weaver, 2017). Island tourism has grown rapidly due to the uniqueness of its destinations and was often seen to be exclusive as it offered unique experiences compared to mainland tourism (Uysal and Modica, 2016). Generally, tourists are attracted to an island site's scenery, nature, or a variety of natural resources (Romao, Neuts, Nijkamp, and Shikida, 2014). Small islands draw tourists because they evoke emotions of remoteness and solitude, tranquillity, and timelessness. The unfamiliarity of new and unknown places increases their appeal for tourists to be away from their usual home surroundings (Keane, 1992).

Smallness has a significant impact on the island tourism structure. A small island, in fact, typically means a much less robust natural resource base (Stylidis, Terzidou and Terzidis, 2007). The critical commodities impacted by tourism rivalry seem to be water, land land, and energy supplies, both of which are considered costly to manufacture or import 
(Manologlou, Tsartas and Markou, 2004). This results in a high reliance on foreign trade, dependent on an inadequate supply of products and a restricted variety of markets (Pearce and Robinson, 1987).

Compared to mainlands, small islands have limited accessibility, which may result in higher transportation costs, limited supplies, lesser tourists, limited infrastructure and higher prices of products and services (Alipour and Kilic, 2005). Wing (1995) claimed that if an island is not accessible to the outside world through air or sea transport, especially to the major tourist trigger countries, tourism development can only take place on a small scale. This explains why a significant number of islands remain underdeveloped and have a stagnant socio-economic system.

The undiversified market is one of the small island's characteristic. Normally, islands with a single or two-industry economy are unable to invest significantly in tourism marketing or expand their product offerings (Stylidis, Terzidou and Terzidis, 2007). This adversely affects their ability to contend with the thousands of other tourist destinations, especially mainlands (Poetschke, 1995). Connell (1988) argues that for small islands with limited resources, practically only assets with a comparative advantage are warm water and weather, clean beaches, unpolluted oceans, and unique cultures. As a matter of fact, since islands' landscapes and natural beauty are among their primary assets, they must conserve them to stay competitive in the industry. This will require islands to impose additional restrictions on tourists activities. On the other hand, protection of the environment can make it increasingly challenging to fulfil the tourist's positive experiences (Poetschke, 1995).

In Malaysia, the history of island tourism started since the Dutch colonisation of Malaya in the 16th century (Din, 1993). According to Othman and Rosli (2011), the four Malaysian islands of Langkawi, Pangkor, Perhentian Island and Tioman had been internationally recognised for their potential in attracting tourists (Arabamiry, Rahim and Khademfar, 2013). Island tourism was not emphasised in the Second Malaysia Plan (1971-1975), but in the Third Malaysia Plan (19761980), Malaysia's government has provided funds to facilitate and develop tourism in the archipelago off Peninsular Malaysia's east coast.

Malaysian island tourism development can be classified into many zones. Peninsular Malaysia's east coast was divided into two archipelagos of islands: Redang, Perhentian, and Kapas in the north, and Aur, Babi Besar, Pemanggil, Rawa Sibu, Tioman, and Tengah in the south. On Peninsular Malaysia's west coast, tourism development extended from north to south, encompassing the islands of Besar, Langkawi, Pangkor and Penang. In the East Malaysian state of Sabah, the island archipelago with the greatest potential for tourism development included the islands of Sapi, Suluq, Gaya, Mamutik, Sapi, and Manukan (collectively referred to as Tunku Abdul Rahman Marine Park), as well as Selingan in the Sulu Sea, Ligitan, Kapai, Pandanan, Mabul, and Sipadan in the Sulawesi and Layang-Layang in the South China Sea (Mapjabil, 1999).

As presented in Table 1, Malaysia has 878 islands (Kaos, 2015). Sabah has the highest number of islands in Malaysia and is one of the most active states in naming islands and other geographical features. Most of the unnamed islands in Sabah have been gazetted and given names to avoid other countries staking a claim on them; currently, there are 394 official islands in Sabah's territory (Morphi, 2011). 
Table 1. Island in Malaysia (Source: Kaos, 2015)

\begin{tabular}{|c|c|}
\hline State/Federal Territory & Number of Islands \\
\hline Kedah & 117 \\
\hline Terengganu & 76 \\
\hline Pahang & 32 \\
\hline Johor & 67 \\
\hline Selangor & 20 \\
\hline Perak & 28 \\
\hline Kelantan & 34 \\
\hline Negeri Sembilan & 9 \\
\hline Malacca & 17 \\
\hline Penang & 10 \\
\hline Perlis & 1 \\
\hline Labuan & 7 \\
\hline Sabah & 394 \\
\hline Sarawak & 69 \\
\hline
\end{tabular}

The rise of new markets has increased competition in island tourism. Numerous small islands worldwide face the difficulty of attracting and sustaining tourists. Determining tourist experience is a critical component of managing tourist destinations (Ismail, 2009). Failure to consider the tourist experiences determinant that influences tourists satisfaction can result in a negative experience and negative word-of-mouth for the small island to follow suit.

\section{Tourist Experiences}

The tourist experiences have been argued to be crucial to building a mutually beneficial relationship between tourists and service providers (Raschid, 2011). Tourism's underlying attribute is that the product or service are purchased on-site, with tourists acting as consumers, and the consumptions process focuses upon tourists' subjective or emotional reactions. The end product of the tourism process is personal experiences, which depend upon the tourists' engagement (Smith, 2002). Thus, the tourists' experience of their on-site interactions with the places they visit provides valuable insights into enhancing tourist satisfaction.

Tourist experiences occur when a service provider intentionally uses service as the primary instrument and goods as supplementary props to establish a connection with tourists (Pine and Gilmore, 2011). In the minds of tourists, experiences should be intimate, unforgettable, and long-lasting. It can be unforgettable in both positive and negative ways; for example, excellent service results in positive outcomes and vice versa. Tourists are engaged on a physical and emotional basis that varies according to the tourist. Moreover, if the impressions are transient until the service is rendered, they can remain fresh in the tourist's memory for a longer period of time.

Tourist experiences are not a new concept in tourism literature; nevertheless, the idea of tourist experiences remains complex, uncertain, and subjective (Cetin and Dincer, 2013). Holbrook and Hirschman (1982) described experiences as 
interactions that elicit feelings and fantasies. Pine and Gilmore (2011) build on the idea of tourist experiences in their book Economic Experiences. According to the researchers, experiences have become the latest economic offerings, and service providers are concentrating their efforts on staging pleasant and memorable experiences in the final step of economic progression by adding value to their offerings. Tourist experiences synthesise resources that have an emotional, physical, intellectual, and spiritual effect on tourists (Mossberg, 2007).

Although these definitions indicate the absence of shared meaning, they describe specific common characteristics of tourist experiences. The first common characteristic is that experiences are unique and personal; they influence tourists' perception and involvement and emotionally engage them. Secondly, experiences also are shared with others and are remembered for an extended period of time (Cetin and Dincer, 2013). Thus, tourist experiences as lasting memories that engage tourists emotionally and personally in relation to their interaction with the physical and social environment result in satisfaction and positive response.

Tourist experiences are a subjective state of mind experienced by tourists. When a tourist visits a destination, a number of destination attributes or features contribute to the overall tourist experiences. Researchers also associate destination attributes with pull factors, which are a combination of amenities and facilities and destination attractions that entice people to visit a specific location. These pull factors could include a range of goods and services and tourist attractions and the destination's climate (Cong, 2016). Although the majority of island destination attributes are identical to those of mainland destinations, they can have their unique pull factors, such as beaches, beach activities, island tours, local food, and climate. Tourists who visit islands spend most of their time on the beaches. They interact with locals and service personnel. Many tourists learn about a new culture, explore local cuisine, and indulge in other recreational activities on the islands.

Moreover, tourist experiences incorporate mechanics and humanism into service delivery (Kandampully, Zhang and Jaakkola, 2018). In an organisational context, tourist experiences refer to the physical environment, while the humanistic aspect refers to social interactions. The physical environment refers to product and supporting facilities and emotional and sensual value associated with the service, such as sounds, sights, and smells. Social interaction can be classified into two broad categories: experiences between service providers and tourists and interactions between tourists.

Malaysia comprises the mainland and the patches of the island. Mainland and small islands are two distinct landmasses with significantly different area dimensions and a history of dynamic shifts in their geological and ecological characteristics (Insani and Takai, 2020). The tourist experiences on the small island and the mainland are different. Unlike the tourist experience on the mainland, small islands' spectacular nature and environment can be preserved due to their geological distance and isolation. Tourists come into contact with these unique physical and social environments on an island, which may affect their perception of tour experiences in term of value for money and the reasonableness of the price paid (Moon and Han, 2018)

In comparison to the mainland, islands' infrastructure and resources can be inadequate. For instance, public transportation may be limited, and the number of retail shops may be fewer than on the mainland (Moon and Han, 2018). Local people on small islands will have meaningful engagement with tourists than their counterparts on mainland resorts, simply due to their smaller geographic proximity and concentrated infrastructure (Ismail, 2009).

In the sense of small islands, achieving positive tourist experiences is critical for service providers. Although there is a substantial body of literature devoted to the study of tourist experience, there is no consensus on the factors 
contributing to its creation. Various researches have been done to uncover the determinants of tourist experiences in small islands context. For instance, Yang, Ge, Ge, Xi and Li (2016) study the island tourism determinants in Dachangshan Island and state that island natural resources are the main determinants; transportation, social and economic factors are endogenous change determinants, and tourist enterprises and source markets subject to government policies the exogenous factors. While Musa, Kadir, and Lee (2006) conducted a study on Sipadan Island, Malaysia, shows that the island's marine life and corals are the main attraction for tourists.

Malaysia is a country that is geographically blessed with islands. One of most well-known islands in Malaysia is LayangLayang Island, which is famous for its diving activities, hammerhead sharks and other pelagic marine life. Despite having hosted tourists (particularly divers) for nearly two decades, Layang-Layang Island is much under-researched.

\section{Layang-Layang Island}

Layang-Layang Island is situated in the South China Sea, about 290 kilometres northwest of Sabah's northwest coast (see Figure 1) and is one of the most thrilling diving destinations in the world, renowned for its hammerhead sharks. This island, which rises nearly 2000 metres above the ocean floor, is an atoll composed of 13 connected coral reefs. The island is one of more than 600 islands, reefs, and shoals in the South China Sea collectively referred to as The Spratlys. This rectangular-like island has various undersea sceneries, coral reefs, fish reefs including oceanic animals that are considered attractive to divers. Layang-Layang Island was originally founded when a senior Malaysian state official visited the Spratly islands and declared the area of Layang-Layang Island as a part of Malaysia territory (Musa et al., 2006).

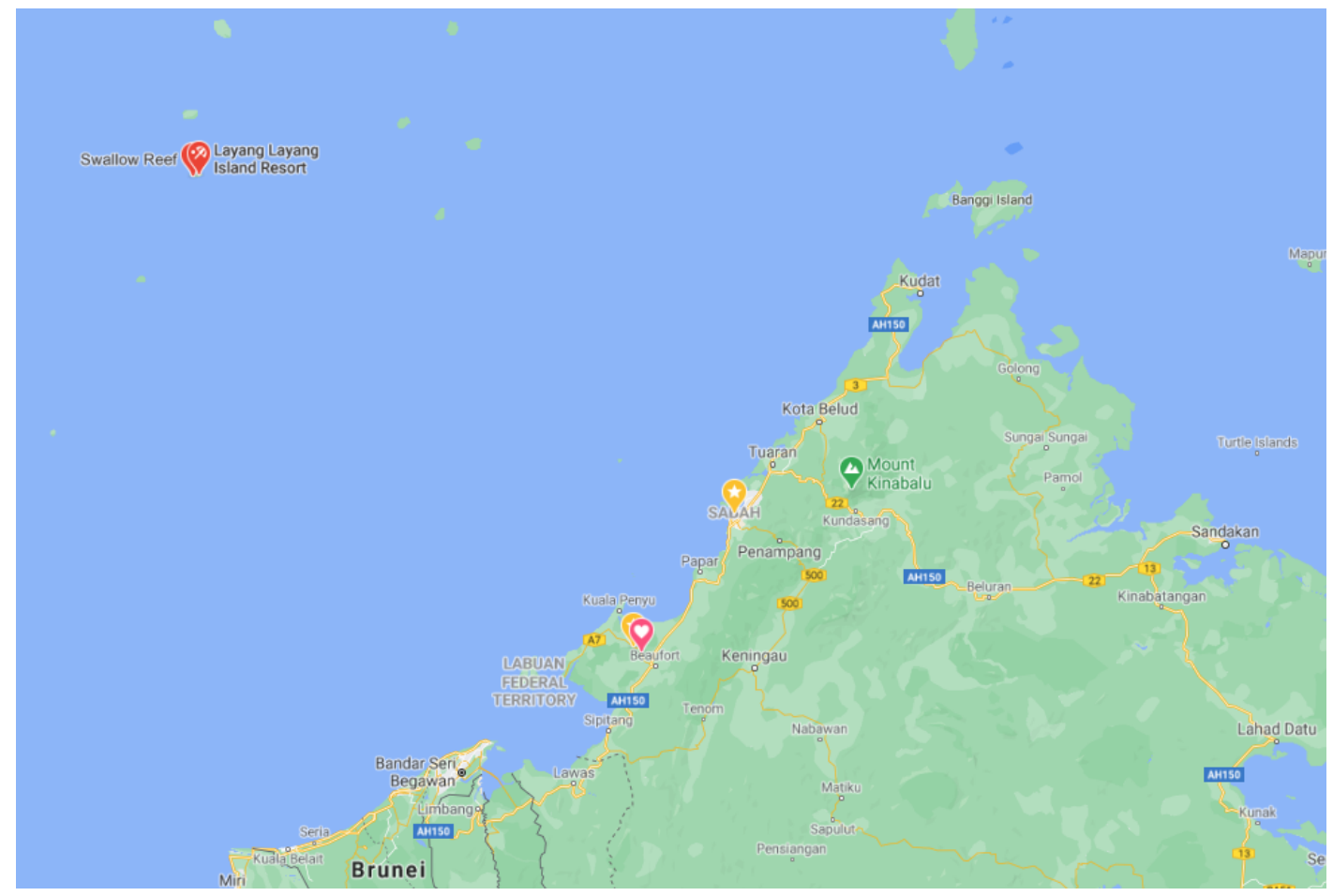

Fig 1. Location of Layang-Layang Island (Source: Google Maps) 
According to Musa et al. (2006), originally, the island was a remote sandbank in the South China Sea. Between 1985 and 1989 , the first reclamation work has been carried out, using fill material transported by barges from the mainland. The island has been further extended between 1991 and 1994 by the building of sea walls, and now measures $1.2 \mathrm{~km} 200 \mathrm{~m}$ in length. It is surrounded by 13 coral atolls that are connected over a 7-kilometre-long and 2-kilometre-wide area, forming a relatively calm lagoon with two major channels from the sea (see Figure 2). Around the rim of the atoll is a $2000 \mathrm{~m}$ sheer drop. Its waters are warm $\left(22-32^{\circ} \mathrm{C}\right)$, with an average visibility of around $30-60$ metres. The deep water and pristine walls host a variety of large fish, including Napoleon Wrasse, Manta Ray, Giant Humphead Wrasse, Hawkbill Turtles, Dog Tooth Tuna, and even shark species. The outstanding visibility makes it possible to examine a number of soft and hard corals in deep water. Layang-Layang Island is also a stopover point for a variety of migratory bird species.

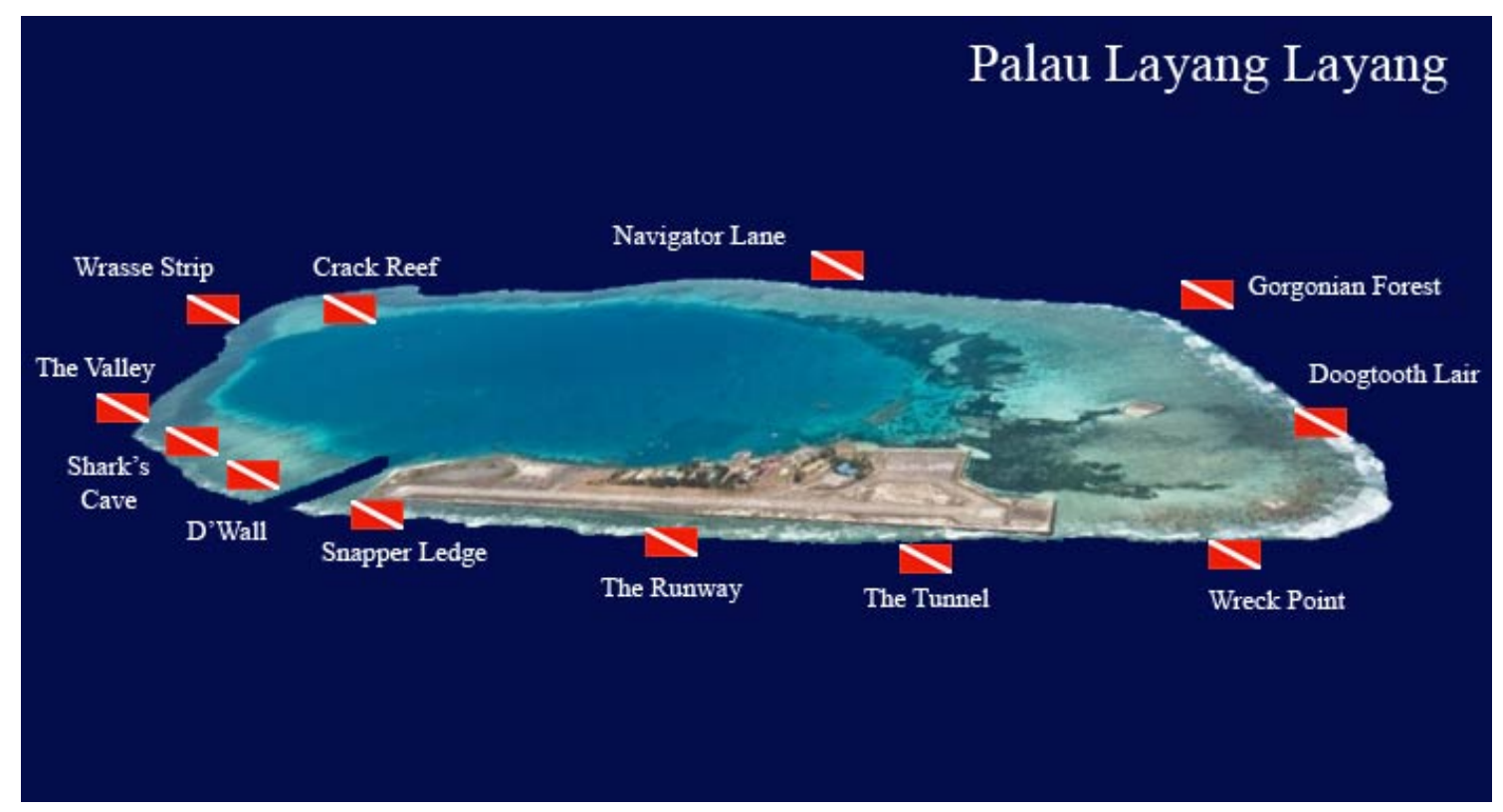

Fig 2. Layang-Layang Island dive sites (Source: https://divezone.net/)

In 1991, the island's first resort opened with 15 rooms and two suites; by 2020, the resort had extended to 86 rooms. In 1992, the Royal Malaysian Navy established a base on Layang-Layang Island. Malaysia Airlines began providing flight service to Layang-Layang Island in 1993, using Twin Otter aircraft with a seating capacity of 8-12 passengers. Additionally, liveaboard vessels frequented the island, which needed 18 cruising hours to reach the nearest mainland (Musa et. al, 2006).

Layang-Layang Resort is the island's only dive operator and lodging provider. The three-star resort is constructed entirely of tropical hardwood and is built in the style of a longhouse. It features many of the amenities identified with an international hotel, such as air conditioning and private bathrooms with hot water showers. The hotel features 86 tourist rooms and four suites spread over six buildings, as well as a freshwater pool and a restaurant serving Asian and Continental dishes. Each space features a television, a refrigerator, and a private balcony. The resort employs 40 to 45 employees, about $90 \%$ of whom are Sabahans (Musa et. al, 2006). During the northeast monsoon, the resort is closed for three months (November to January). A limited number of employees (approximately 4 to 6 ) remain behind during this off-peak time to perform resort maintenance tasks. 
To minimise the environmental effect of scuba diving operations, the resort adheres to a stringent environmental protection strategy and requires all divers to sign its Reef Conservation Pledge, which is part of its Environmental Conservation Program. The on-site PADI (Professional Association of Dive Instructors) dive centre features welcoming and knowledgeable dive masters, rental facilities, and a comprehensive dive course menu. Additionally, the resort provides snorkelling, bird watching, a jetty stroll, and snooker.

\section{Methods}

Zhang and Cole (2016) claimed that there was a limitation in the practice of conventional tourism research methods such as survey and interviews to assess tourist experience due to the poor response rates, fieldwork costs, and selfreporting bias. Due to the massive use of Web 2.0 websites, specifically online review sites, tourists can also rely on reviews written by other tourists who have chosen to leave comments, assisting them in their decision-making process, since reviews are typically written by tourists with no commercial desires, and therefore are considered trustworthy and authentic (Au, Buhalis and Law, 2014).

More researchers confirm the importance of online review platforms such as TripAdvisor for electronic word of mouth (e-WOM) and customer's feedback in the tourism industry (Oliveira et al., 2019). Zhang and Cole (2016) reported that compared to editors "review, tourists are more likely to trust other tourists" reviews. The current study is based on an analysis of online reviews from TripAdvisor.com, the world's biggest travel site with over 385 million traveller reviews and its organisation, TripAdvisor Inc., has a market capitalisation of nearly US\$5.5 billion (Bloomberg, 2019).

For two decades, since its inception in 2000, TripAdvisor has been under academic scrutiny from various fields. At the time of writing of this article (December 2020), a simple search from Google Scholar yielded 192,000 results using the word 'TripAdvisor' alone. To date, TripAdvisor has expanded from merely publishing travel experience reviews to a website that offers reservations or bookings for travellers. Apart from the online reviews, information that was available on the website includes service providers and reviewers information, which is essential to identify the market segment.

The data set was obtained from the publicly accessible TripAdvisor website with a total of 118 out of 141 review comments (https://tripadvisor.com/). The researchers chose only reviews in the English language. Thereafter, the Leximancer software was used for the analysis of qualitative content, as the said software is capable of analysing qualitative textual documents, extracting data and displaying the results visually (Kivunja, 2013). Leximancer software was used for content analysis because it is capable of analysing scattered bits of data from text using nonlinear dynamics and machine learning algorithms. The most fundamental units in Leximancer's textual pattern extraction process are words, concepts, and themes (Figure 1). Lemon and Hayes (2020) explained that the most commonly occurring words in text are found first and then grouped to uncover concepts. These are then grouped into higher-level themes that help in visualisation and are depicted as coloured circles on a design diagram, with the main theme represented in red, followed by orange, and so on.

Leximancer software does both thematic and contextual studies (Harwood, Gapp, and Stewart, 2015). Leximancer minimises analytical biases caused by presumptions about the data generated during data collection and facilitates analyses by enabling reliable and reproducible findings (Harwood et al., 2015). Penn-Edwards (2010) illustrated Leximancer's value as an investigative tool that enables the researcher to examine large amounts of data without bias, identify more syntactic properties, enhance reliability, and enable reproducibility. Harwood et al. (2015) further noted 
that, while not sufficient to substitute for human coding at the selective coding level, Leximancer illustrated good similarities to main emergent themes from grounded theory analysis and provided a good crosscheck of completeness in the open coding stage.

There is other textual analysis software that could summarise tourists' experiences such as CATPAC and Wordle by categorising the most extensive word occurrences and their co-occurrence by factor analyses approaches (Zhang and Cole, 2016). However, the Leximancer software was able to provide an inductive identification of themes with minimal interference from the researchers (Tkaczynski, Rundle Thiele, and Cretchley, 2015). Additionally, the Leximancer programme has been used in recent years to conduct research in a number of tourism-related contexts (Brochado, Stoleriu, and Lupu, 2018).

Leximancer created lists and relationships from the collected text (Angus, Rintel and Wiles, 2013) which was deemed a reliable statistic. Different themes can emerge by utilising computerised model list conception, as Leximancer extracting substantial conceptual material and thematic information directly from the data document. For this study, A customised taxonomy was developed as a concept diagram, highlighting critical concepts and their relationships(Angus, Rintel, and Wiles, 2013). As shown in Figure 3, pertinent connections are made between the major themes. Leximancer has been used in recent tourism research to address issues of tourist experiences in island tourism (Oliveira et al., 2019), Airbnb lodging (Cheng and Jin, 2019), and surf camps (Brochado et al., 2018).

Penn-Edwards (2010) demonstrated Leximancer's usefulness as an analytical technique by demonstrating how it enables researchers to analyse vast volumes of data objectively, recognise additional syntactic properties, increase reliability, and allow reproducibility. Leximancer was not adequate to replace human coding at the selective coding level; it demonstrated strong parallels to the major emergent themes from grounded theory research and served as a useful crosscheck of completeness during the open coding stage.

\section{Findings}

\section{Respondents' Profile}

The profiles of the 118 respondents are presented in Table 2. Most of the respondents were from Singapore, the United Kingdom and Australia. Respondents from Malaysia comprised $11 \%$ only while the other $89 \%$ comprised international tourists. Respondents mostly travelled with friends, as a couple or solo. Less than $6 \%$ of the respondents were travelling with family or for business purposes.

In addition, TripAdvisor website also provided data for tourist ratings of Layang-Layang Island, as presented in Table 3. Overall, $71.63 \%$ of the respondents rated Layang-Layang Island positively, with $32.62 \%$ being an excellent rating and other $39.01 \%$ as rated the island as very good. Another $15.6 \%$ of the respondents rated the island as average while $12.77 \%$ rated Layang-Layang Island as poor (4.26\%) and terrible (8.51\%). 
Table 2. Respondents' Nationality and Trip Type (Source: TripAdvisor)

\begin{tabular}{|l|l|l|l|l|l|}
\hline \multicolumn{1}{|c|}{ Respondent's Nationality } & \multicolumn{1}{|c|}{ Frequency } & \multicolumn{1}{c|}{ Percentage } & \multicolumn{1}{c|}{ Respondent's Trip Type } & Frequency & \multicolumn{1}{c|}{ Percentage } \\
\hline Singapore & 19 & 16.10 & Friends & 53 & 44.92 \\
\hline The United Kingdom & 17 & 14.41 & Couple & 37 & 31.36 \\
\hline Australia & 16 & 13.56 & Solo & 21 & 17.80 \\
\hline Malaysia & 13 & 11.02 & Business & 4 & 3.39 \\
\hline Hong Kong & 11 & 9.32 & Family & 3 & 2.54 \\
\hline The United States of America & 10 & 8.47 & & & \\
\hline France & 3 & 2.54 & & & \\
\hline China & 3 & 2.54 & & & \\
\hline Thailand & 3 & 2.54 & & & \\
\hline United Arab Emirates & 3 & 2.54 & & & \\
\hline Brunei Darussalam & 2 & 1.69 & & & \\
\hline New Zealand & 2 & 1.69 & & & \\
\hline Brazil & 2 & 1.69 & & & \\
\hline Others & 14 & 11.86 & & & \\
\hline Total & 118 & 100 & Total & & \\
\hline
\end{tabular}

Table 3. Tourist Rating (Source: TripAdvisor)

\begin{tabular}{|l|l|l|}
\hline \multicolumn{1}{|c|}{ Rating } & \multicolumn{1}{c|}{ Frequency } & Percentage \\
\hline Excellent & 46 & 32.62 \\
\hline Very Good & 55 & 39.01 \\
\hline Average & 22 & 15.60 \\
\hline Poor & 6 & 4.26 \\
\hline Terrible & 12 & 8.51 \\
\hline Total & 141 & 100 \\
\hline
\end{tabular}

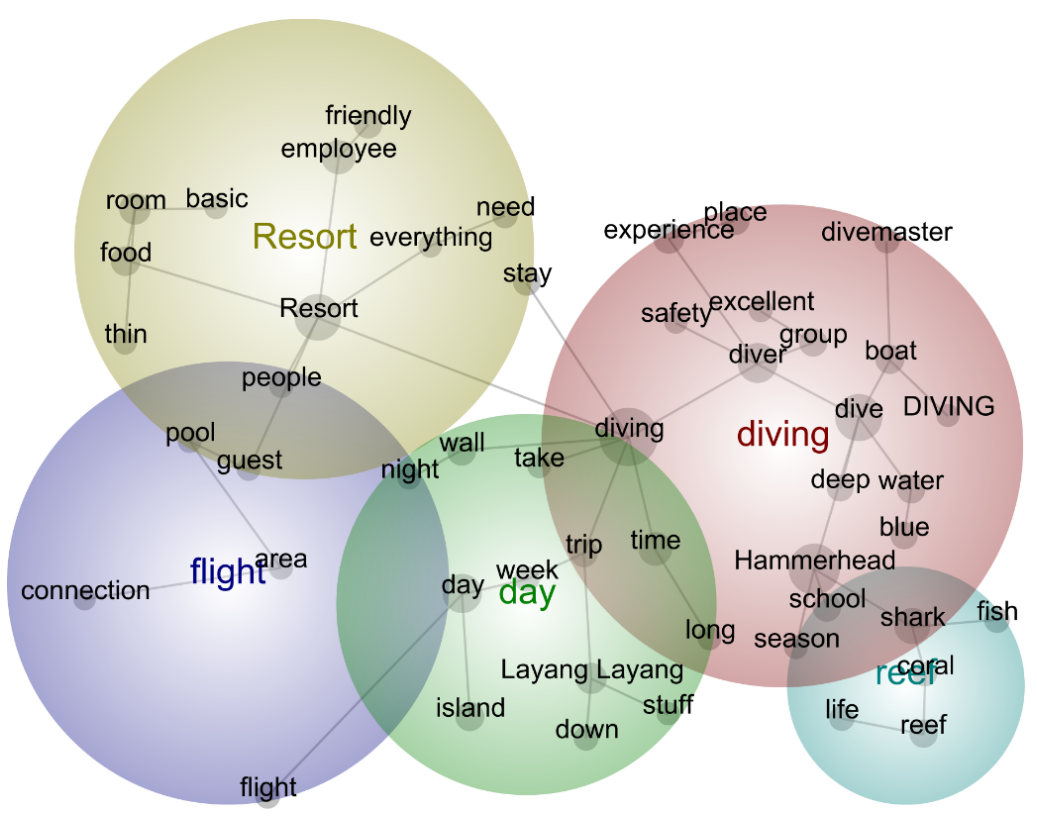

Fig 3. Concept map generated for tourist experience in Layang-Layang Island 
In order to answer the research question of this study, a concept map was generated that illustrated the common themes and concepts derived from the TripAdvisor online reviews. This concept map displays concepts as nodes, which are then clustered into themes and depicted by wider shaded circles (see Figure 3). Five themes are identified and ranked according to their number of hits, as presented in Figure 4. The themes consisted of diving, Resort, day, flight and reef.

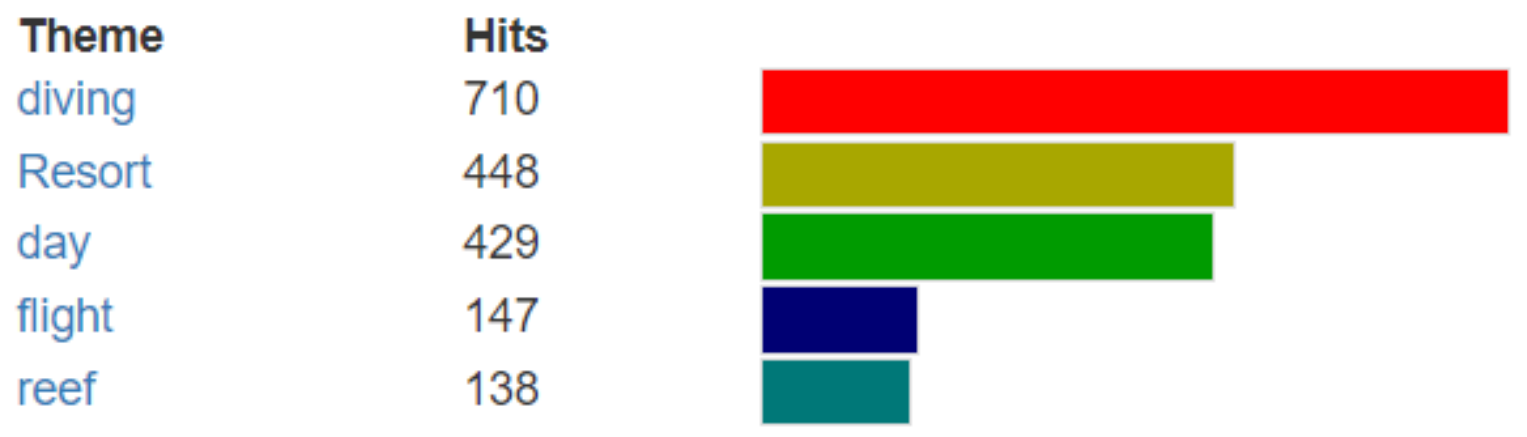

Fig 4. Hits generated for each main theme

\section{Theme: Diving}

The most prominent theme associated with the tourists' experience in Layang-Layang Island was diving. With 710 hits, the diving theme consisted of the concepts such as "diving", "Hammerhead", "dive", "diver", "shark", "time", "experience", "boat", "place", "school", "water", "group", "blue" and "deep". Layang-Layang Island is one of the world's most well-known sites among the diving community for its hammerhead sharks (Musa et al., 2006), and has been considered as one of the top ten dive locations in the world (Sabah Tourism, 2020). For example, respondents wrote:

Wonderful dive for a school of a Hammerhead sharks! An island where you can escape from the busy city life and focus for diving and meet a school of Hammerhead sharks at the deep blue water, swim with a manta ray! (Malaysia, Travelling with friends)

My best dive trip ever! I am so glad that I joined this dive trip arranged by Scuba Knights to Layang-Layang last week. This island is such a unique place where we could see Hammerhead sharks, big fat white tip sharks, Jacks, Grand Trevallies, Turtles and many more species at different dive spots just 5 mins away by boat from the resort. (Hong Kong, Travelling with friends).

However, there were also negative comments associated with "diving" as respondents have high expectations of the diving experience and unfortunately failed to experience it. For example:

The only problem is that you will most likely NOT see a huge school of Hammerhead sharks migrating around you, even in the peak season (I saw one!). There are probably few reasons for this: too many divers in the water at the same time - we spent nearly every dive waiting for around 15-20 minutes in the blue at around $30 \mathrm{~m}$ off a point where a shark had been spotted a few days before but not just the twelve divers on our boat but the other three boats of divers as well! (Singapore, Travelling with friends)

When you go to Layang-Layang, you are paying to do the deep dives to hopefully see the hammerhead sharks migrating. We saw not a single one. (United Kingdom, Traveling as a couple). 
Diving is a unique ocean experience, and the experience much depends on the place and the of a dive; in other words, it is based on one's luck to be able to encounter the unique wildlife in the massive ocean. Some respondents were able to rationalise their experience. For instance:

The diving is insane. The corals are untouched, and the fishes are plentiful. The hammerheads only appeared for us twice in the five days we spent there, but hey, they are wild creatures after all. (Singapore, Travelling solo)

\section{Theme: Resort}

With 448 hits, the Resort theme consisted of the concepts such as "Resort", "employee", "room", "food", "friendly", "thin", and "stay". There is only one exclusive resort currently operating on Layang-Layang Island. The resort owned by LayangLayang Resort Sdn Bhd has 86 rooms and is currently rated as a three-star resort which opens only from February 28 to September 1 every year (http://layanglayang.com). The design of the resort was inspired by the traditional Long House and it comprises rooms, restaurant and bar, swimming pool, and a dive centre with certified diving instructors (http://tripadvisor.com). For the resort, the themes "employee", and "friendly" were mentioned by respondents in a positive manner, but "food" and "room" were not:

The resort has seen better days, and although the employees are friendly and helpful, the room and food are average. (Japan, Travelling as a couple)

The employees working in the resort are well trained, 100 percent passionate to make sure the tourists have an enjoyable stay (Dubai, Travelling as a couple)

The room is clean - bed, pillow, blanket, bed sheet is good quality and comfortable. Not bad, but there is room for improvement. Resort: Very friendly employees, but the room are olds, and you can hear every single noise from your neighbour (Singapore, Travelling solo).

The restaurant has a good selection of Asian and European food. The resort has a big enough pool and friendly employees.

The resort was basic but ok for the diver, the employees were very kind and helpful. I liked the food, but my husband could not eat much of it, it depends on taste. (Thailand, Travelling as a couple)

In addition, it was noteworthy that a few respondents made special remarks regarding the "thin" walls. For example:

Quality of sleep is quite bad actually as walls are paper thin and you can hear the TV or next-door people chatting and this could be extremely irritating when you are trying to sleep to wake up early for the dive the next day. (Malaysia, Travelling with Friends)

Rooms are ok, the bed could be bigger and more comfortable, and the walls are indeed quite thin but no way as bad as we were expecting based on previous reviews. (United Kingdom, Travelling as a couple).

\section{Theme: Day}

The day theme with 429 hits incorporated concepts such as "day", "Layang-Layang", "Island", "wall" and "trip". As most of the respondents associated their experiences of Layang-Layang Island with the term "trip" and "wall", all respondents viewed these concepts positively. For instance: 
The diving was good. We did see the Hammerhead shark, and the wall was pretty spectacular (Singapore, Travelling with friends).

... I have movies of great quality of some of the best dives I ever had. The dive normally starts at 7am, going deep, 35 to 40 meters. This is the Hammerhead dive. All dives you do here are wall dives, and you will always see a shark - always! (Abu Dhabi, Travelling with friends)

The dive route is descending from the speed boat, then diving into the blue for 15 mins to look for the hammerheads. After 15 mins, go back to the wall dive. During my stay period, a four-speed boat goes out in every dive, and always at least 1 group of divers can see the hammerhead. Beside the sharks, there are many other things to see (Hong Kong, Travelling as a couple).

However, as we continued to dive, we went to a great wall with excellent underwater vistas and some great healthy coral. (Singapore, Travelling with friends)

\section{Theme: Flight}

The flight theme had 147 hits; linked concepts are "area" and "connection". The only mode of transport to visit LayangLayang Island is via a one-hour duration flight from the north of Kota Kinabalu, the capital city of Sabah.

There were only three days in a week which has scheduled flights in and out of Layang-Layang: Sunday, Tuesday and Friday. I booked my flight and trip to Layang-Layang many months in advance with a diving agent (Asia Diving Vacation, operated and owned by Duis Dive Sdn Bhd.) and was confirmed morning flight to and from the island from Kota Kinabalu. The agent then confirmed my flight again when I arrived in Kota Kinabalu (United States of America, Travelling with friends)

The booking of the flight is handled with your resort booking. (United Kingdom, Travelling as a couple).

The only way in and out of the atoll is via a chartered flight. This is probably one of the few places in the world where you can lie down and gaze at the stars or capture a time-lapse of the Milky Way galaxy above you, literally on the runway. (Singapore, Travelling with friends)

Layang-Layang has obviously had its heyday. It has since deteriorated and is now picking itself up so you can see things are being improved - the extra cost of a return flight to the remote island is probably a bit of a barrier to many compared with more accessible places but it is well worthwhile. (Australia, Travelling as a couple).

Other than a means of transportation, a respondent linked "flight" as one of the attributes for his or her experience. For instance:

The flight was part of the excitement and added to our overall experience. Our first aerial view of LayangLayang sitting in its perfect lagoon isolated in the bright blue sea is something I won't forget. (United Kingdom, Travelling with friends)

\section{Theme: Reef}

The reef theme with 138 hits was associated with "reef", "coral" and "fish". There were 14 coral reefs that existed around Layang-Layang Island, which created breathtaking underwater scenery. The dive sites are well known for the intriguing hammerhead sharks and pygmy seahorses, among other rare sea creatures. 
Its reefs are so amazingly beautiful and full of life, from pelagic to macro. Truly a unique getaway (Malaysia, Travelling with friends).

Beautiful coral reefs took my breath away. And we were so lucky to spot the schooling hammerheads twice in nine dives! (Hong Kong, Travelling with friends).

The reefs were gorgeous and healthy, and worth spending a long time with. Lots of big life (reef mantas, sea turtles, napoleon wrasse, white tip reef sharks, pick handle barracudas, chevron barracudas, giant trevally and jacks). (Australia, Travelling with friends)

Great reefs with lovely corals, plenty of fish, mantas, white tips, gray reef sharks and the jewel in the crown, those astounding hammerhead schools, one in a lifetime experience! (Spain, Travelling with friends)

...reef was rich with healthy corals and vibrant aquatic life. Every dive had something different, even when the visibility was down a bit because of the big swell the reef had something to capture your attention. (Australia, Travelling as a couple)

However, there were some respondents who did not perceive the reef as fascinating. For example:

The reef itself isn't great and whilst the walls can be good with reef shark and manta sightings if you're going for Hammers you've got to be in the blue! (United Kingdom, Travelling as a couple).

The reefs are not that interesting, but we did get to see an Eagle Ray and a Bull shark around the reefs (Oman, Travelling with friends)

Nothing much to see at the reefs and shallower waters, so it was a disappointing trip. (Singapore, Travelling with friends).

The reef is not as colourful as some we have seen, but the underwater life is very good. (Australia, travelling as a couple)

\section{Discussion}

The aim of this study was to examine tourist experiences on Layang-Layang Island and to identify their main themes based on tourists' narratives in online reviews. The findings have potential significance for the literature because they contribute to a better comprehension of the tourist experience in the context of the much-understudied Layang-Layang Island. Based on the data in Table 2, most of the respondents $(71.63 \%)$ rated it as 'excellent' and 'very good'. This showed that most of the respondents had a positive experience in Layang-Layang Island, and in order to explore their indepth experiences, the researchers had utilised content text analysis.

Researchers such as Zhang and Cole (2016) and Oliveria et al. (2019) demonstrated the value of using content text analysis of online reviews as a supplement to conventional methods to provide valuable insight into tourist experiences on small islands. Hence, this has enabled the generation of the most significant dimensions of tourist experiences. There were five themes generated from the Leximancer software, namely diving, Resort, day, flight and reef.

The main theme for tourist experience in the Layang-Layang Island was 'diving'. The diving experience has been the central focus in numerous tourist experience research, especially in the island tourism context. Type of research, location of research, and themes were the key to assessing tourist experience and they could be classified as scuba market profile and travel intention, scuba diving impacts and the management of scuba (Schoeman, Van der Merwe and 
Slabbert, 2016). From the results, the main attraction of Layang-Layang Island was definitely the hammerhead sharks; this was a well-known fact among the diving community (Musa et al., 2006) and Layang-Layang has been considered as one of the top ten dive locations in the world (Sabah Tourism, 2020). This was reiterated by one of the respondent reviews:

Wonderful dive for a school of Hammerhead sharks! An island where you can escape from the busy city life and focus on diving and meet a school of Hammerhead sharks in the deep blue water, swim with a manta ray! (Malaysia, Travelling with friends).

Additionally, Lee and Smith (2015) asserted that the most important experience dimensions for tourists are escape and entertainment. Diving, reef and wall were the essential combinations to provide the best entertainment and escape for the tourists. The island was known for excellent visibility, reef, coral and steep walls down to $2000 \mathrm{~km}$ (Sabah Tourism, 2020). This was mentioned by one of the respondents:

The diving was good. We did see the Hammerhead shark, and the wall was pretty spectacular (Singapore, Travelling with friends).

Accommodation played a significant role that contributed to the total tourist experience. Souza et al. (2020) suggested experience realm for accommodation context referred to aesthetic dimension, as it was found to be strongly predictive of experiential outcomes such as overall quality experience and satisfaction. The only accommodation available on the island was the Layang-Layang Island Resort which first opened in 1991 with only 15 bedrooms and currently, the resort was able to accommodate 86 bedrooms. However, due to the rather remote location, this had led to a scarcity of essential goods. However, the resort managed to offer a basic necessity for accommodation, as mentioned by one of the respondents:

The room is clean, bed, pillow, blanket, bed sheet is good quality and comfortable. Not bad, but there is room for improvement. Resort: Very friendly employees, but the rooms are old, and you can hear every single noise from your neighbour (Singapore, Travelling solo).

According to Souza et al. (2020), the tourist experience is influenced by their interaction and engagement with the destination's services and people and seems to induce cognitive, emotional, and behavioural responses. With the constraints in terms of aesthetic value, the resort strived to enhance tourist experience through their employees and services as mentioned by one of the respondents:

The employees working in the resort are well trained, 100 percent passionate to make sure the tourists have an enjoyable stay (Dubai, Travelling as a couple).

Lastly, the growing number of online reviews and their contents on Layang-Layang Island showed the importance of promoting the island as a remarkable tourist destination. It is recommended that the resort should further improve its attributes such as the bedrooms and other facilities. Currently, the resort operated as a three-star hotel, but in the long run, it would be best to upgrade it to a luxury resort for the creation of an ultimate island escape.

\section{Conclusion}

Despite having hosted tourists (particularly divers) for nearly two decades, Layang-Layang Island is much underresearched; thus, this study aims to assess tourist experiences in Layang-Layang Island. Leximancer software was 
utilised to analyse the data online reviews extracted from the TripAdvisor website and generates themes. Five themes were derived from the data analysis which flight, resort, diving, day and reef. The findings provide insights into the determinants of tourist experiences that could assist resort management in further designing their product and service to achieve positive tourist experiences that can enhance tourist satisfaction. These results also could assist policymakers in delineating strategies to further develop Layang-Layang Island as one of the top island destinations.

Even with the insightful outcomes, this study does have limitations that should be highlighted. There is only one island was reviewed, and no consistent data about reviewers' profiles were available. Thus, additional studies can be conducted on similar small Malaysian islands, such as Mantanani Island. Additionally, the determinants of tourist experience identified in this study can be correlated in the future to reviewers' demographic and psychographic characteristics changes, as well as the growing number of online reviews for Layang-Layang Island.

\section{Competing Interest Statement}

All authors have read and approved the manuscript and take full responsibility for its contents. The authors have declared that no competing interest exists.

\section{Acknowledgements}

This work is supported by the Universiti Malaysia Sabah under the Research Code TR@M001-2019 research grant titled Sumber Semulajadi Dan Potensi Pembangunan Strategik Ekonomi Luar Pantai Malaysia: Pulau Layang-Layang.

\section{References}

Alipour, H., Kilic, H., 2005. An institutional appraisal of tourism development and planning: The case of the Turkish Republic of North Cyprus (TRNC). Tourism Management, 26(1):79-94. doi:10.1016/j.tourman.2003.08.017

Angus, D., Rintel, S.,Wiles, J., 2013. Making sense of big text: A visual-first approach for analysing text data using Leximancer and Discursis. International Journal of Social Research Methodology, 16(3):261-267.

Arabamiry, S., Rahim, K. A., Khademfar, M., 2013. Choice modelling state preference valuation technique in Perhentian Island Marine Park environmental goods. International Journal of Business and Social Science, 4(6):179-188.

Au, N., Buhalis, D., Law, R., 2014. Online complaining behavior in mainland China hotels: The perception of Chinese and non-Chinese customers. International Journal of Hospitality and TourismAdministration,15(3):248-274.

Bass, S., Dalal-Clayton, B., 1995. Small island states and sustainable development: strategic issues and experience. Environmental Planning Group International Institute for Environment and Development. https://pubs.iied.org/sites/default/files/pdfs/migrate/7755IIED.pdf

Bloomberg, 2019. Online reviews remain a trusted source of information when booking trips, reveals new research. Retrieved from https://www.bloomberg.com/press-releases/2019-07-16/online-reviews-remain-a-trusted-source-of-information-when-booking-trips-revealsnew-research

Brochado, A., Stoleriu, O., Lupu, C., 2018. Surf camp experiences. Journal of Sport and Tourism, 22(1):21-41.

Cetin, G., Dincer, F. I., 2013. Influence of customer experiences on loyalty and word-of-mouth in hospitality operations. Anatolia, 25(2):181-194. https://doi.org/10.1080/13032917.2013.841094 
Chen, C. F., Chen, F. S., 2010. Experience quality, perceived value, satisfaction and behavioral intentions for heritage tourists. Tourism Management, 31(1):29-35.

Cheng, M., Jin, X., 2019. What do Airbnb users care about? An analysis of online review comments. International Journal of Hospitality Management, 76:58-70.

Conlin, M., Baum, T.G., 1995. Island Tourism: Management Principles and Practice. John Wiley and Sons, Chichester.

Connell, J., 1988. Contemporary issues in island tourism, IN: Pacione, M., The Geography of the Third World: Progress and Prospect, London: Routledge

Cong, L. C., 2016. A formative model of the relationship between destination quality, tourist satisfaction and intentional loyalty: An empirical test in Vietnam. Journal of Hospitality and Tourism Management, 26:50-62.

Din, K. H., 1993. Dialogue with the hosts: An educational strategy towards sustainable development. In Hitchcock M, VT King \& Parnwell M (Eds.), Tourism in South East Asia. Routledge, London.

Harwood, I. A., Gapp, R. P., Stewart, H. J., 2015. Crosscheck for completeness: Exploring a novel use of leximancer in a grounded theory study, 20(7):1029-1045 https://doi.org/10.46743/2160-3715/2015.2191

Hassenzahl, M.,Tractinsky, N., 2006. User experience - A research agenda. Journal Behaviour and Information Technology, 25(2):91-97.

Holbrook, M. B., Hirschman, E. C., 1982. The experiential aspects of consumption: Consumer fantasies, feelings, and fun. Journal of Consumer Research, 9(2):132-140. https://doi.org/10.1086/208906

Insani, H., Takai, M., 2020. Mainland versus island adaptation: Paleobiogeography of sunda shelf primates revisited. Pleistocene Archaeology Migration, Technology, and Adaptation. https://doi.org/10.5772/intechopen.90051

Ismail, F., Alipiah, R. M., Mansor, N., Shukri, W. H. W. Z., 2020. A cross-cultural study of destination attributes: Impact on sustainability of island tourism. Journal of Sustainability Science and Management, 15(1):1-14. https://jssm.umt.edu.my/wpcontent/uploads/sites/51/2020/05/1.15.1pdf.pdf

Ismail, F., 2009. The development of small island tourism in Malaysia (Thesis). Victoria Library University. https://vuir.vu.edu.au/30065/1/Fathilah\%20Ismail_Part1.pdf

Jennings, M., Stoker, L., Bowers, J., 2009. Politics across generations: Family transmission reexamined. The Journal of Politics, 71(3):782-799. doi:10.1017/s0022381609090719

Kandampully, J., Zhang, T., Jaakkola, E., 2018. Customer experiences management in hospitality. International Journal of Contemporary Hospitality Management, 30(1):21-56. https://doi.org/10.1108/ijchm-10-2015-0549

Kaos, J., 2015. Sabah has the highest number of islands. The Star Online. https://www.thestar.com.my/news/nation/2015/08/23/sabah-hasthe-highest-number-of-islands

Keane, M., 1992. Rural tourism and rural development. In H. Briassoulis, \& J. van der Straaten, Tourism and the environment. Dordrecht, NL: Kluwer Academic Publishers.

Kivunja, C., 2013. Qualitative data mining and knowledge discovery using Leximancer digital software. Lecture Notes on Information Theory, 1(1):53-55.

Kurniasari, K., 2019. Understanding visitors' experiences in nature-based tourism: A case study of Komodo National Park Indonesia (thesis). Auckland University of Technology. https://openrepository.aut.ac.nz/handle/10292/12984

Lee, T. H., Jan, F., Tseng, C. H., Lin, Y. F., 2018. Segmentation by recreation experience in island-based tourism: A case study of Taiwan's Liuqiu Island. Journal of Sustainable Tourism, 26(3):362-378.

Lee, H., Smith, S., 2015. A visitor experience scale: Historic sites and museums. Journal of China Tourism Research, 11(3):255-77. 
Lemon, L., Hayes, J., 2020. Enhancing trustworthiness of qualitative findings: Using leximancer for qualitative data analysis triangulation. The Qualitative Report. https://doi.org/10.46743/2160-3715/2020.4222

Manologlou, E., Tsartas, P., Markou, A., 2004. Geothermal energy sources for water production-socio-economic effects and people's wishes on Milos island: A case study. Energy Policy, 623-633. https://doi.org/10.1016/s0301-4215(02)00315-4

Mapjabil, J., 1999. Pelancongan di Pulau Mabul: Impak terhadap masyarakat nelayan (Unpublished master's dissertation). Universiti Kebangsaan Malaysia, Bangi, Malaysia.

Moon, H., Han, H., 2018. Tourist experience quality and loyalty to an island destination: The moderating impact of destination image. Journal of Travel \& Tourism Marketing, 36(1):43-59. https://doi.org/10.1080/10548408.2018.1494083

Morphi, M., 2011. All 182 unnamed Sabah islands given names. Borneo Post Online. https://www.theborneopost.com/2011/04/12/all-182unnamed-sabah-islands-given-names/

Mossberg, L., 2007. A marketing approach to the tourist experiences. Scandinavian Journal of Hospitality and Tourism, 7(1):59-74. https://doi.org/10.1080/15022250701231915

Munar, A. M., Jacobsen, J. K. S., 2013. Trust and involvement in tourism social media and web-based travel information sources. Scandinavian Journal of Hospitality and Tourism. 13(1):1-19.

Musa, G., Kadir, S. H. S. L.,Lee, L., 2006. Layang Layang: An empirical study on scuba divers' satisfaction. Tourism in Marine Environments, 2(2):89-102.

Oliveira, C., Brochado, A., Moro, S., Rita, P., 2019. Consumer perception of tourist experience through online reviews. Worldwide Hospitality and Tourism Themes, 11(6):696-717.

Othman, P., Rosli, M., 2011. Impact of tourism on small business performance: Empirical evidence from Malaysian Islands. International Journal of Business and Social Science, 2(1):11-21.

Pearce, J. A., Robinson, R. B., 1987. A measure of CEO social power in strategic decision-making. Strategic Management Journal, 8(3):297304. https://doi.org/10.1002/smj.4250080307

Penn-Edwards, S., 2010. The competencies of an english teacher: Beginning student teachers' perceptions. Australian Journal of Teacher Education, 35(2). https://doi.org/10.14221/ajte.2010v35n2.4

Pine, B. J., Gilmore, J. H., 2011. The experiences economy, Updated Edition (Updated ed.). Harvard Business Review Press.

Poetschke, B., 1995. Key success factors for public/ private- sector partnerships in island tourism planning, In: Conlin, M.V. and Baum, T., 1995, Island Tourism: Management Principles and Practice, Chichester: John Wiley \& Sons Ltd

Prayag, G., Ryan, C., 2012. Antecedents of tourists' loyalty to Mauritius: The role and influence of destination image, place attachment, personal involvement, and satisfaction. Journal of Travel Research, 51(3):342-356.

Raschid, M. Y. M., 2011. Tourism, community and environment: Siting strategies to enhance the tourists' experience in coastal resorts of the West Malaysian Peninsular (Thesis). The University of Melbourne. https://minervaaccess.unimelb.edu.au/bitstream/handle/11343/35892/268408_Matraschid\%20Thesis\%20online.pdf? sequence=1\&isAllowed $=y$

Romao, J., Neuts, B., Nijkamp, P., 2014. Determinants of trip choice, satisfaction and loyalty in an eco-tourism destination: A modelling study on the Shiretoko Peninsula, Japan. Ecological Economics, 107:195-205.

Sabah Tourism., 2020, October 18. Layang Layang island. https://www.sabahtourism.com/destination/layang-layang-island/ Sangpikul, A., 2017. The effects of travel experience dimensions on tourist satisfaction and destination loyalty: The case of an island destination. International Journal of Culture, Tourism, and Hospitality Research, 12(1):106-123. 
Schoeman, K., Van der Merwe, P., Slabbert, E., 2016. The perceived value of a scuba diving experience, Journal of Coastal Research, 32(5):10711080 .

Sheldon, P. J., 2005. The challenges to sustainability in island tourism. Occasional Paper Series, School of Travel Industry Management (TIM), University of Hawaii, United State. 1-12. https://lib.icimod.org/record/11965/files/6127.pdf

Smith, R., 2002. Beach resort evolution: Implication for planning. Annals of Tourism Research, 19:304 - 322.

Souza, L. H., Kastenholz, E., Barbosa, M. D. L. A., Carvalho, M. S. S. C., 2020. Tourist experience, perceived authenticity, place attachment and loyalty when staying in a peer-to-peer accommodation, International Journal of Tourism Cities, 6(1):27-52.

Stylidis, D., M. Terzidou K., Terzidis, K., 2007. Island tourism and its socio-economic impacts, MIBES, 954-967

Tkaczynski, A., Rundle Thiele, S. R., Cretchley, J., 2015. A vacationer-driven approach to understand destination-image, Journal of Vacation Marketing, 21(2):151-162.

Uysal, M., Modica, P., 2016. Island tourism: Challenges and future research directions. In P.Modica \& M.Uysal, Sustainable island tourism: Competitiveness and quality of life, 173-188. CABI: UK.

Weaver, D. B., 2017. Core-periphery relationships and the sustainability paradox of small island tourism. Tourism Recreation Research, 42(1):11-21.

Wilkinson, J., 2010. Assessing the challenge: Development of the challenging behaviour scales. Mental Handicap Research, 2(1):86-104. https://doi.org/10.1111/j.1468-3148.1989.tb00017.x

Wing, P., 1995. Development and marketing of international tourism in small island states, In: Conlin, M.V. and Baum, T., 1995, Island Tourism: Management Principles and Practice, Chichester: John Wiley \& Sons Ltd

Yang, J., Ge, Y., Ge, Q., Xi, J., Li, X., 2016. Determinants of island tourism development: The example of Dachangshan Island. Tourism Management, 55:261-271. https://doi.org/10.1016/j.tourman.2016.03.001

Zhang, Y., Cole, S., 2016. Dimensions of lodging tourist satisfaction among tourists with mobility challenges: A mixed-method analysis of webbased texts. Tourism Management, 53:13-27. 